\title{
The Medial Ganglionic Eminence Gives Rise to a Population of Early Neurons in the Developing Cerebral Cortex
}

\author{
Alexandros A. Lavdas, ${ }^{1}$ Maria Grigoriou, ${ }^{2}$ Vassilis Pachnis, ${ }^{2}$ and John G. Parnavelas ${ }^{1}$ \\ 1Department of Anatomy and Developmental Biology, University College London, London WC1E 6BT, United Kingdom, \\ and 2Division of Developmental Neurobiology, Medical Research Council National Institute for Medical Research, Mill Hill, \\ London NW7 1AA, United Kingdom
}

During development of the neocortex, the marginal zone (layer I) and the subplate (layer VII) are the first layers to form from a primordial plexiform neoropil. The cortical plate (layers II-VI) is subsequently established between these superficial and deep components of the primordial plexiform neuropil. Neurons in the early zones are thought to play important roles in the formation of the cortex: the Cajal-Retzius cells of the marginal zone are instrumental in neuronal migration and laminar formation, and cells of the subplate are involved in the formation of cortical connections. Using the fluorescent tracer 1,1'dioctodecyl-3,3,3',3'-tetramethylindocarbocyanine (Dil), we have shown here that a substantial proportion of neurons of the marginal zone, including cells with features of Cajal-Retzius cells, and of the subplate and lower intermediate zone are not born in the ventricular neuroepithelium but instead originate in the medial ganglionic eminence (MGE), the pallidal primordium. These neurons follow a tangential migratory route to their positions in the developing cortex. They express the neurotransmitter GABA but seem to lack the calcium binding protein calretinin; some migrating cells found in the marginal zone express reelin. In addition, migrating cells express the LIMhomeobox gene $\operatorname{Lhx} 6$, a characteristic marker of the MGE. It is suggested that this gene uniquely or in combination with other transcription factors may be involved in the decision of MGE cells to differentiate in situ or migrate to the neocortex.

Key words: Cajal-Retzius cells; subplate; intermediate zone; medial ganglionic eminence; neuronal migration; neocortex; Lhx6 expression
One of the early events in the regionalization of the brain is the subdivision of the dorsal and basal telencephalic ventricular zones (VZs). The dorsal VZ, a sheet of pseudostratified epithelial cells, gives rise to the neocortex, whereas the dome-shaped ventral VZ produces the striatum and pallidum, components of the basal ganglia that receive major inputs from the neocortex. This elevation protruding into the ventricular cavity becomes divided by a sulcus into a lateral and a medial part, known respectively as the lateral ganglionic eminence (LGE) and medial ganglionic eminence (MGE). A prominent corticostriatal sulcus divides the neocortical and striatal regions and separates cells with different molecular traits and markedly different fates (Rubenstein et al., 1994; Fishell, 1995). In the mature brain, the cortex contains a wide range of neuronal cell types that are organized in six layers (Szentágothai, 1973), whereas the striatum has a nuclear organization largely composed of one neuronal cell type, the medium spiny cell (Kemp and Powell, 1971).

A number of studies have shown that although neuronal precursors are able to move within the dorsal and basal VZs, they are unable to cross the corticostriatal sulcus (Fishell et al., 1993; Neyt et al., 1997), which suggests, in accordance with the widely held view, that cortical neurons originate exclusively from progenitor

Received Jan. 25, 1999; revised June 25, 1999; accepted June 30, 1999.

The work was supported by the Medical Research Council. M.G. is a recipient of a European Union fellowship (No. ERBFMBICT 961297). We thank Drs. K. Nakajima and M. Ogawa for the generous supply of the CR-50 antibody, Chun-Hung Chan for help with a number of experiments, and Harry Uylings for his thoughtful and expert suggestions on this manuscript.

Drs. A. Lavadas and M. Grigoriou contributed equally to this work.

Correspondence should be addressed to John G. Parnavelas, Department of Anatomy and Developmental Biology, University College London, Gower Street, London WC1E 6BT, UK.

Copyright (C) 1999 Society for Neuroscience $0270-6474 / 99 / 197881-08 \$ 05.00 / 0$ cells within the dorsal VZ. Thymidine autoradiography and electron microscopical studies indicated that postmitotic neurons migrate away from their place of origin toward the pial surface, using radial glial fascicles as guides, and assemble in an "insideout" pattern within the cortical plate (Rakic, 1974, 1988). The exception to this inside-out sequence of laminar formation is the Cajal-Retzius cells of the marginal zone (MZ), which together with the neurons of the subplate (SP) are the first cells to appear in the cerebral cortex (for review, see Uylings et al., 1990; MarínPadilla, 1998). A number of investigations have highlighted important roles for Cajal-Retzius cells in neuronal migration and cortical lamination (D'Arcangelo et al., 1995; Ogawa et al., 1995; Frotscher, 1997) and for SP neurons in the formation of cortical connections (McConnell et al., 1994; Ghosh, 1995).

Recent experimental findings, however, have challenged this concept of cortical neuronal generation and migration. First, tracing experiments have shown that cells in the embryonic LGE are able to transgress the corticostriatal boundary and migrate into the developing neocortex (De Carlos et al., 1996; Anderson et al., 1997; Tamamaki et al., 1997). Second, these and other tracing studies (O'Rourke et al., 1995) and a host of investigations with recombinant retroviruses (Walsh and Cepko, 1992; Mione et al., 1997), chimeric and transgenic mice (Soriano et al., 1995; Tan et al., 1995, 1998), and bromodeoxyuridine incorporation (De Diego et al., 1994) have provided evidence that a significant proportion of cortical neurons do not migrate to their destinations along radially oriented glial fascicles but rather along nonradial pathways. In the present study we have shown that the MGE is a source of cells in the MZ, including Cajal-Retzius cells, and of neurons in the lower intermediate zone (IZ) and SP at various stages of corticogenesis. These cells follow a tangential 
migratory route to their positions in the developing cortex. The origin, migration, and distribution of these early neurons coincides with the pattern of expression of the novel LIM-homeobox gene Lhx6 in the developing telencephalon (Grigoriou et al., 1998) and, indeed, we found that these cells do express this transcription factor.

\section{MATERIALS AND METHODS}

Animals. Brains of embryos, removed from pregnant Sprague Dawley albino rats at different stages during the last week of gestation [embryonic day 13-19 (E13-19); E1, day vaginal plug was found], were used for the preparation of slice cultures and for in situ hybridization for Lhx6. In situ hybridization for this gene was also performed on brain sections of mice (Parkes; outbred) of different embryonic stages (E11.5-19.5).

Materials. DMEM/F12 culture medium was purchased from Sigma (St. Louis, MO), and Neurobasal medium and B-27 medium supplement were purchased from Life Technologies (Gaithersburg, MD). Antibodies used in this study were rabbit anti-Lhx6 (Grigoriou et al., 1998), rabbit anti-GABA (Sigma), rabbit anti-calretinin (CR) (Swant, Switzerland), mouse anti-reelin (CR-50) (Ogawa et al., 1995), fluorescein-conjugated goat anti-rabbit, and biotinylated goat anti-rabbit and goat anti-mouse (Vector Laboratories, Burlingame, CA). Other materials used were 1,1'dioctodecyl-3,3,3', $3^{\prime}$-tetramethylindocarbocyanine (DiI) (Molecular Probes, Eugene, OR), avidin and biotin (Vector), fetal calf serum (FCS) (Life Technologies), normal goat serum (NGS) (Seralab, Sussex, UK), Geys balanced salt solution (GBSS) (Life Technologies), $30 \mathrm{~mm}$ culture plate inserts (Millipore, Bedford, MA), agar (BDH), Clearmount aqueous mounting medium (Zymed); penicillin/streptomycin, gentamycin solution, and diaminobenzidine (DAB) tablet sets were all purchased from Sigma.

Preparation of slice cultures. Pregnant rats at different stages of gestation $(\mathrm{E} 13, n=3$; E14, $n=14$; E15, $n=6$; E16, $n=17$; E17, $n=8$; E18, $n=$ 3; E19, $n=6$ ) were killed by cervical dislocation. The fetuses were rapidly removed and placed in GBSS at $4^{\circ} \mathrm{C}$ supplemented with glucose $(6.5 \mathrm{mg} / \mathrm{ml})$. The following procedures were performed under sterile conditions. The brains were removed and placed in a $3 \%$ solution of agar in $0.1 \mathrm{M}$ PBS, $\mathrm{pH} 7.2$, at $40^{\circ} \mathrm{C}$; agar was subsequently hardened on ice. Most brains were cut with a Vibratome coronally at $400 \mu \mathrm{m}$, and a few were cut in the sagittal plane. Slices were kept in GBSS/glucose at $4^{\circ} \mathrm{C}$ for $50 \mathrm{~min}$ to allow for deterioration of enzymatic activity released by damaged cells. Slices were placed onto millicell CM membranes in 30 $\mathrm{mm}$ Petri dishes containing $1 \mathrm{ml}$ of DMEM/F12 with $6.5 \mathrm{mg} / \mathrm{ml}$ glucose, $0.1 \mathrm{~mm}$ glutamine, $50 \mathrm{mg} / \mathrm{ml}$ penicillin/streptomycin, and $10 \%$ FCS for 1 $\mathrm{hr}$, after which the cultures were kept in Neurobasal medium supplemented with B27 (1:50), with $6.5 \mathrm{mg} / \mathrm{ml}$ glucose, $0.1 \mathrm{~mm}$ glutamine, and $50 \mathrm{mg} / \mathrm{ml}$ penicillin/streptomycin.

Injection of fluorescent tracer. To examine the migratory pathways of neurons generated in the ganglionic eminences, we placed crystals of DiI with a glass micropipette in the MGE $(n=200)$ or LGE $(n=10)$ of one hemisphere of cultured slices derived from a range of embryonic ages (E13-19) (Fig. 1A-C). After placement of DiI, cultures were incubated for a further $48 \mathrm{hr}$ in Neurobasal medium as described above and then fixed in $4 \%$ paraformaldehyde in PBS for $3 \mathrm{hr}$. They were subsequently rinsed in PBS, coverslipped, and observed with a fluorescent microscope or a laser-scanning confocal microscope.

To disturb the migration of neurons arising in the ganglionic eminence, slices containing both hemispheres were placed under a stereomicroscope after the first hour in DMEM/F12, and a cut was made with a scalpel that spanned the thickness of the cortex in one hemisphere at the level of the corticostriatal junction (Fig. 1D). A wedge-shaped piece of sliced agar was then placed inside the cut to prevent reconnection of the cut surfaces and cell movement between the two sides. The culture medium was then replaced, and cultures were incubated for a further 48 hr before fixation with $4 \%$ paraformaldehyde in PBS for $3 \mathrm{hr}$.

In situ hybridization. We used nonradioactive in situ hybridization on fresh-frozen sections of mouse and rat embryos to examine the expression of $\operatorname{Lh} x 6$ in the developing telencephalon. Sections were cut with a cryostat in the coronal plane at $25 \mu \mathrm{m}$ and collected on gelatinized slides. After fixation with $4 \%$ paraformaldehyde in PBS, in situ hybridization was performed as described previously (Schaeren-Wiemers and GerfinMoser, 1993; Grigoriou et al., 1998). Antisense riboprobes were generated using $1.5 \mathrm{~kb} \mathrm{BamHI-EcoRI}$ fragment of the 3'UTR of the mouse Lhx6 cDNA (Grigoriou et al., 1998).
Immunocytochemistry. To further characterize DiI-labeled cells, selected slice cultures that had been observed with the microscope and photographed were removed from the slides, re-embedded in agar, resectioned at $75 \mu \mathrm{m}$ with the Vibratome, and immunolabeled for GABA, CR, $\operatorname{Lh} x 6$, or CR-50. Sections were incubated in PBS containing $0.05 \%$ Triton $\mathrm{X}-100$ and $10 \% \mathrm{NGS}$ at room temperature for $1 \mathrm{hr}$, and then with the antibody diluted 1:1000 (GABA, CR, $L h x-6$ ) or 1:400 (CR-50) in PBS with $0.005 \%$ Triton X-100 and $10 \%$ NGS at $4^{\circ} \mathrm{C}$ overnight. After three 5 min washes in PBS, sections were incubated in fluorescein-conjugated goat anti-rabbit (GABA, CR, $L h x 6$ ) or goat anti-mouse (CR-50) diluted 1:50 in PBS for $3 \mathrm{hr}$. Stained sections were mounted in Clearmount and observed using a laser-scanning confocal microscope.

Immunolabeling was also performed in the lesioned slice cultures. In these preparations, cortices were separated from the rest of the slice using a razor blade and transferred into a different Petri dish. They were dissociated, embedded in agarose, and immunostained as described by Vaccarino et al. (1995). According to this method, the medium was washed away with $0.1 \mathrm{M}$ PBS, and slices were dissociated with $0.25 \%$ trypsin containing $0.003 \%$ EDTA. Forty minutes later, the cell suspension was centrifuged at $200 \times g$ for 3 min, the supernatant was removed, and the cells were resuspended and fixed with $4 \%$ paraformaldehyde in PBS for $1 \mathrm{hr}$. They were subsequently washed in PBS and resuspended in a solution of $1.8 \%$ low gelling point agarose in $0.1 \mathrm{M} \mathrm{PBS}$ at $45^{\circ} \mathrm{C}$. The agarose solution containing the cells was then poured between two glass slides separated by two No. 1 coverslips and was left to set in the refrigerator for $10 \mathrm{~min}$. Pieces of the agarose films containing the cells were subsequently incubated with anti-CR (1:1000) or anti-GABA (1: $500)$ antibodies. The bound immunoglobulins were visualized with the avidin-biotin method using DAB as substrate. The stained agarose films were mounted on slides (in PBS/glycerol), and fields of labeled cells were observed under the microscope. The total number of cells and the number of immunostained cells per field were counted in randomly selected fields with the use of a $250-\mu \mathrm{m}$-square reticule under a $20 \times$ objective lens. A minimum of 10 fields ( $\sim 400$ cells) were counted in each of three separate experiments, and the proportions of immunostained cells in the whole-cell population was calculated for each experiment. Student's $t$ test was used to compare the mean percentages of cells stained with each antibody in the control group with those in the cortices from the lesioned cultures.

\section{RESULTS \\ Expression of Lhx6 in the developing MGE and neocortex}

We have previously reported (Grigoriou et al., 1998) that the LIM-homeobox containing gene Lhx6 is expressed in the subventricular and submantle zones of the mouse MGE from E11.5 to E17.5. Careful examination of our sections revealed that in addition to the ventral telencephalon, Lhx6 is also expressed in specific subsets of cells in the developing neocortex. In mouse embryos, the earliest Lhx6-expressing cells of the cortex first appeared at E13.5 as a column of cells bordering the ventricular zone and connected to the basal MGE (Fig. $2 A$ ). A few scattered Lhx6-expressing cells were also present at this stage in the LGE. At subsequent developmental stages (E15.5-17.5), the number of cells expressing Lhx6 in the LGE was greatly reduced, but expression of this gene was also observed in cells of the MZ, SP, and IZ of the developing cortex (Fig. $2 B$ ). To determine whether the pattern of expression of $\operatorname{Lhx} 6$ in the mouse brain is conserved in other mammalian species, we performed in situ hybridization analysis on sections of rat embryonic forebrain at comparable developmental stages (E14-19). Similar to mouse embryos, we detected high levels of expression of Lhx6 in the MGE of these rats. Lhx6-expressing cells were also present in the neocortex in a spatial and temporal pattern similar to that observed in mouse embryos (Fig. 2C,D). It has recently been shown (De Carlos et al., 1996; Anderson et al., 1997; Tamamaki et al., 1997) that progenitor cells generated in the LGE of the basal telencephalon migrate dorsally and contribute to the GABA-expressing population of interneurons of the cortex. The spatial and temporal pattern of 

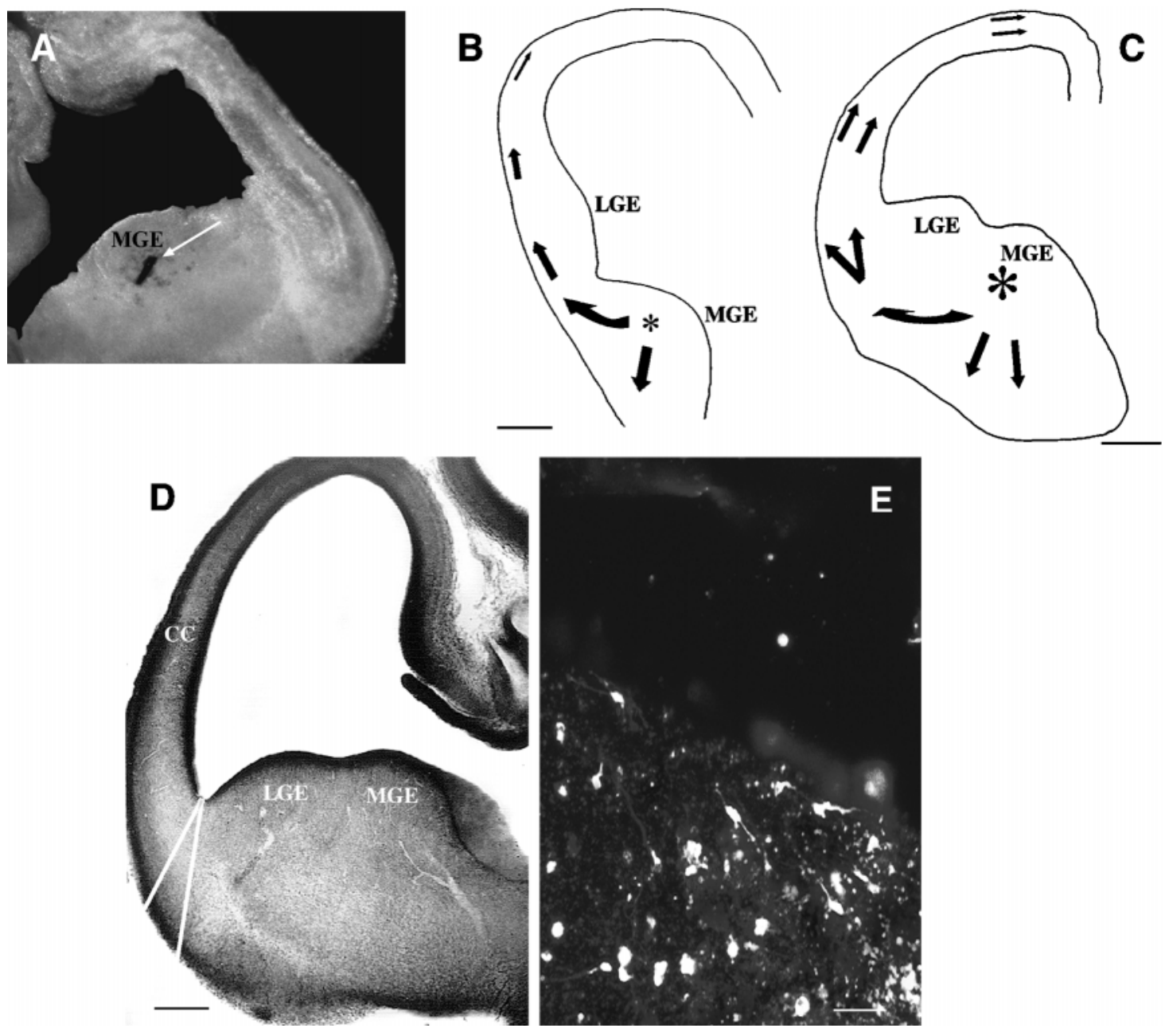

Figure 1. A, Placement of DiI crystals (arrow) in the MGE of a $400 \mu \mathrm{m}$ coronal slice through the brain of an E16 rat and maintained in culture for $1 \mathrm{~d}$. $B, C, C$ amera lucida drawings of coronal sections through part of the rat forebrain after placement of DiI crystals in the MGE (asterisks) at E14 ( $B$ ) and E16 $(C)$. Arrows indicate the direction of migration of labeled cells in the cortical primordium $2 \mathrm{~d}(B)$ and $3 \mathrm{~d}(C)$ after DiI application. In $B$, fluorescent cells appeared as a stream rounding the corticostriatal sulcus and heading toward the preplate. In $C$, migrating cells were seen in the most superficial and the deeper aspects of the cortical primordium. To disturb the migration of neurons arising in the MGE, cuts were made with a scalpel in one hemisphere of E16 slices as shown with white lines in $D$. Placement of DiI in the MGE of the lesioned hemisphere resulted in accumulation of labeled cells below the cut $(E)$. Scale bars: $B, 350 \mu \mathrm{m} ; C, 600 \mu \mathrm{m} ; D, 500 \mu \mathrm{m} ; E, 60 \mu \mathrm{m}$.

Lhx6-expressing cells reported here raises the possibility that cells originating in the MGE also migrate dorsally and integrate into the layers of the neocortex.

\section{Neuronal migration}

To investigate whether the pattern of expression of Lhx6 was indicative of a migratory route, we placed crystals of DiI in the MGE of cultured slices prepared from the brains of rat embryos between the stages of E13 and E19 (Fig. 1A) and in the LGE of E16 slices. After $2 \mathrm{~d}$ in vitro (DIV), slices prepared from E13 and E14 embryos displayed numerous labeled neurons emerging from the MGE. A number of these cells were observed traversing the LGE and were directed ventrolaterally, others were found rounding the corticostriatal sulcus and were directed either dorsolaterally or toward the temporal cortex, whereas others appeared to have reached the most superficial aspect of the cortical mantle (preplate) and were oriented parallel to the pial surface (Figs. 1B, $3 A$ ). Many of these tangentially oriented cells showed features typical of Cajal-Retzius cells as described previously in the cortex of rat embryos (Bradford et al., 1977; Derer and Derer, 1990): an irregular or elongated cell body and a long (up to $150 \mu \mathrm{m}$ ), thick leading process that often branched (Fig. $3 B$ ). Slices prepared from E15 and E16 embryos contained a large number of migrating cells that showed a different distribution in the developing cortex (Fig. 1C). As before, DiI-labeled cells were found in the $\mathrm{MZ}$, but now a second group of cells had appeared in the lower IZ, whereas a small number of cells were also seen in the SP and occasionally in the cortical plate (CP) (Fig. $3 C, D$ ). These cells typically had a long and thick leading process emerging from the opposite pole of the cell body. The direction of the thick leading process was regarded as the direction of the cell migration (Fig. $3 D$ ). A similar group of cells in the IZ and SP were seen in slices injected with DiI at E17, but these preparations did not show any labeling in the MZ, even when slices were left in culture for an additional day. However, DiI injections into the MGE of slices prepared from E18 and E19 rats did not result in any labeling in the neocortex. When DiI placements were made in the LGE of E16 cultures, labeled neurons appeared in significant numbers in the IZ and were scattered throughout the CP but not in the MZ, 
Figure 2. Expression of Lhx6 seen in coronal sections through mouse $(A, \mathrm{E} 13.5 ; B, \mathrm{E} 15.5)$ and rat $(C, \mathrm{E} 15 ; D, \mathrm{E} 17)$ embryonic brains. This gene is expressed in high levels in the MGE and in a group of cells emerging from the MGE, rounding the corticostriatal sulcus (arrows in $C$ ) and directed toward the superficial and deep layers of the developing neocortex. Scale bars, $500 \mu \mathrm{m}$.
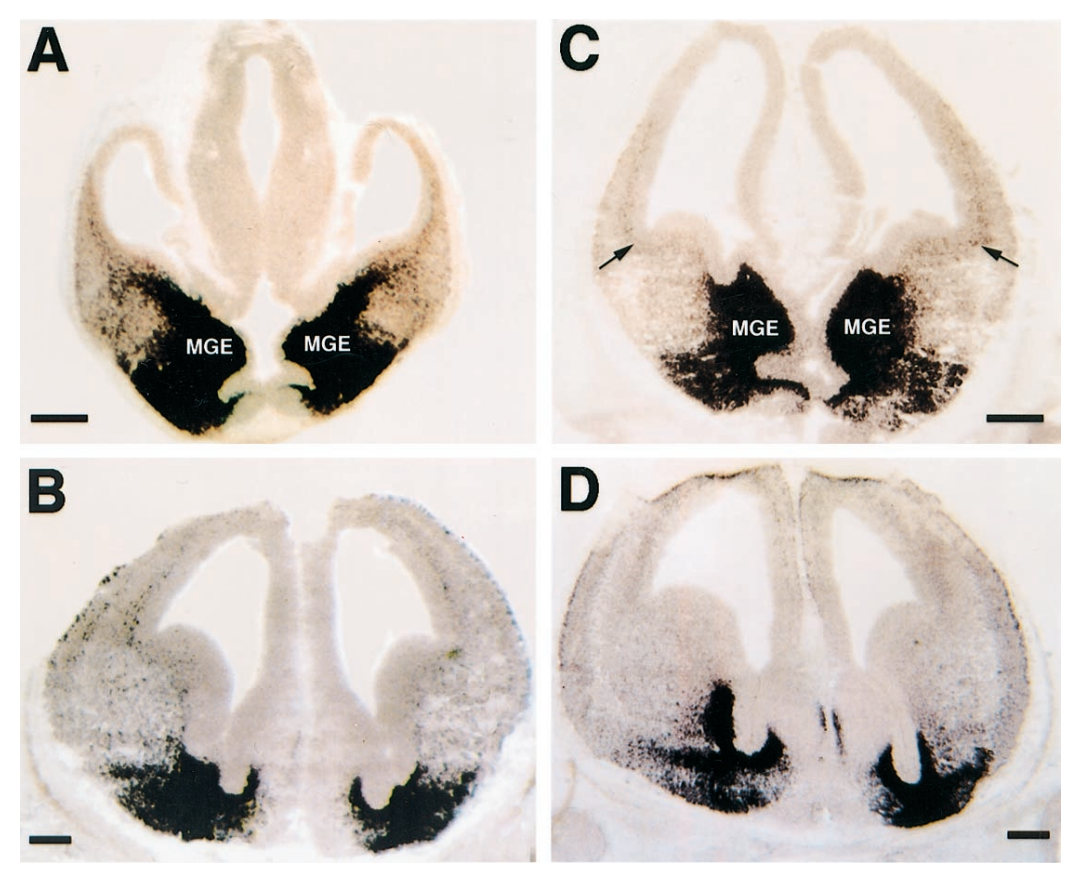

in agreement with the recent observations of Anderson et al. (1997).

In three experiments, slices were cut sagittally from brains of E15, E16, and E17 rat embryos, and crystals of DiI were placed in the MGE. Examination of these slices after 2 or 3 DIV showed some labeled cells in the hippocampus, whereas others had reached the dorsal cortex and had their leading processes oriented caudally. As in the coronally cut slices, DiI-labeled neurons were found in the MZ as well as in the IZ and the SP.

\section{Immunocytochemical characterization of migrating neurons}

We used immunocytochemistry in slices prepared from E15 and E16 rats to characterize further the DiI-labeled cells that originate in the MGE. In these slices we found, in agreement with previous reports (Van Eden et al., 1989; De Diego et al., 1994), that GABA immunoreactivity is restricted for the most part in the MZ, in the SP, and in the lower part of the IZ. Doublelabeling experiments showed that a number of the DiI-labeled cells in the $\mathrm{MZ}$ and the IZ contained GABA (Fig. 4B,E). Immunolabeling of slices for CR revealed staining of cells and their processes in the MZ and the SP. However, despite extensive search, none of the DiI-labeled cells were immunoreactive for this calcium binding protein; these cells were seen intermixed with CR-containing neurons in the MZ and IZ (Fig. 4A).

Immunocytochemistry with an antibody against Lhx6 in slices cut from E15 and E16 embryos showed labeling to be restricted in three bands. These bands corresponded to the MZ, the SP, and the lower IZ. A small number of labeled cells were also seen scattered in the CP. Double-labeling experiments indicated that a number of cells that had migrated from the MGE into the MZ and IZ expressed this transcription factor (Fig. $4 D, F$ ). We also examined the localization of the CR-50 antigen that is associated specifically with Cajal-Retzius cells in the developing neocortex (Ogawa et al., 1995). We found that this antigen is expressed extensively in the MZ of the neocortex in the cultured slices, including cells that originated in the MGE as indicated by the presence of DiI (Fig. 4C).

\section{Lesioned cultures}

We examined the migration of neocortical neurons that originated in the MGE in slices that received a cut through the cortex at the level of the corticostriatal sulcus. We found that after placement of crystals of DiI in the MGE, labeled cells appeared to have migrated toward the corticostriatal sulcus and accumulated below the cut. We also investigated the proportions of the GABA and CR neurons in the intact and lesioned slices. Using agarose films stained for $\mathrm{CR}$, we found that the proportion of neurons that express this calcium binding protein was similar $(t=$ $0.515)$ in the intact and lesioned cultures $(4.6 \pm 0.7$ and $5.2 \pm$ $0.5 \%$ of all cells, respectively). However, using similar preparations, we observed that the proportion of GABA-labeled cells decreased significantly $(t=0.047)$ in the lesioned cultures, falling to a mean of $16.6 \pm 1.8 \%$ of the cortical neurons as compared with $24.5 \pm 2.1 \%$ in the intact slices.

\section{DISCUSSION}

The main findings to emerge from this study are as follows. (1) The MGE is a source of a substantial population of neurons in the MZ, including Cajal-Retzius cells, and of neurons in the SP and the lower portion of the IZ of the developing neocortex. (2) These neurons express the neurotransmitter GABA but do not express CR; reelin was also found in cells destined for the MZ. (3) The proportion of GABA-containing cortical neurons in brain slices is reduced by separating the neocortex from the subcortical telencephalon, but that of CR-expressing neurons remains unchanged. (4) Neurons in the MGE, including those that migrate to the MZ, IZ, and SP, express the LIM homeobox gene Lhx6.

\section{Cell migration from the MGE}

The fluorescent tracer labeling experiments showed that cells emanating from the MGE migrate to the developing neocortex. Cells labeled at the early stages of corticogenesis (E13-14) reach the pial surface and move tangentially underneath it. It is not clear what means they use to reach their destinations in the preplate. Initially, they may use glial fibers that extend ventrolat- 

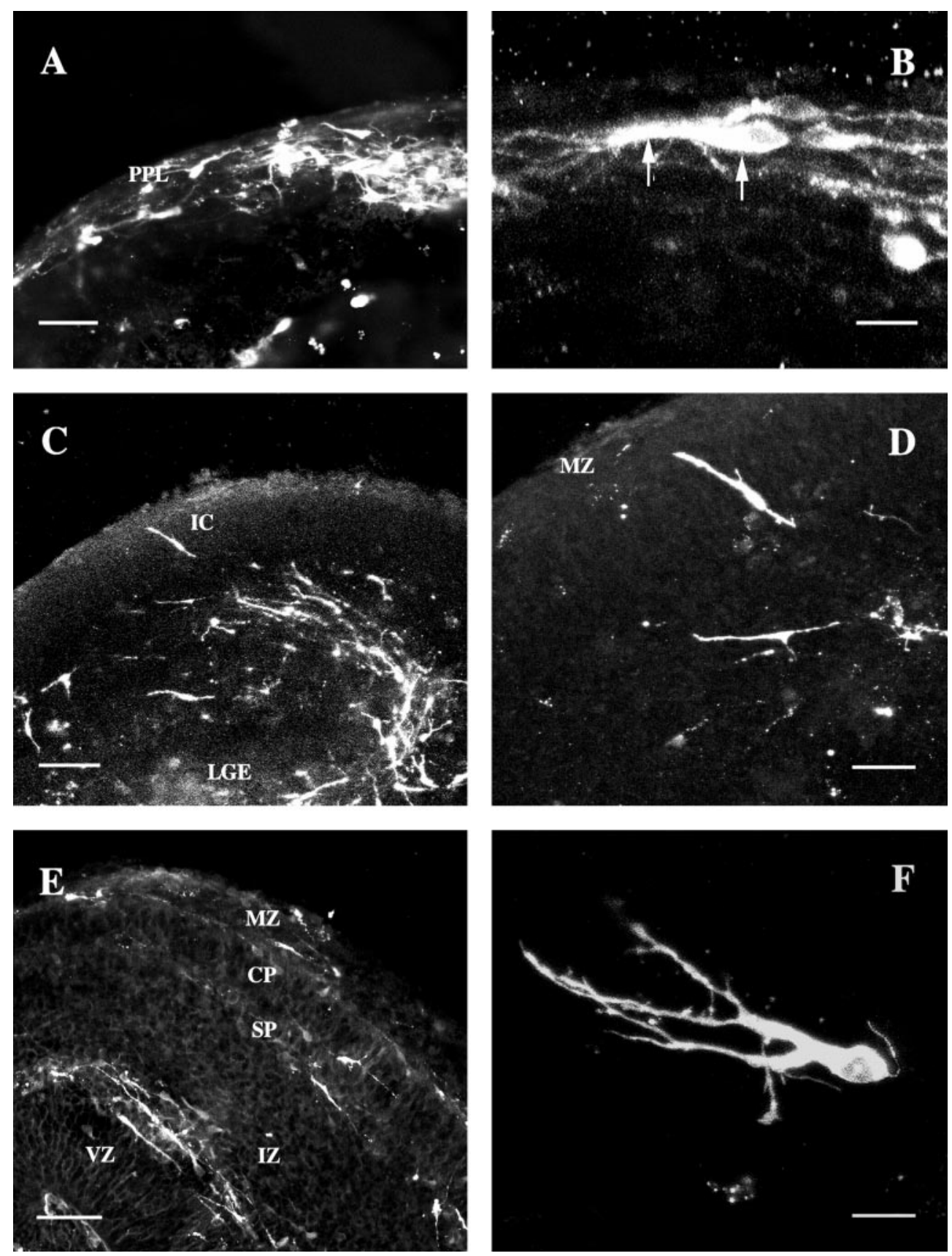

Figure 3. Migrating cells in the cortical primordium labeled by application of DiI in the MGE. $A, B$, In E14 slices, kept in culture for $2 \mathrm{~d}$, labeled cells were restricted to the preplate ( $P P L)$. A number of these cells showed features typical of Cajal-Retzius cells (arrows in $B$ ). $C, D$, In E16 slices, kept in culture for $2 \mathrm{~d}$, migrating cells were seen heading toward both the most superficial and deeper aspects of the cortical primordium. Two of the cells in $C$ are shown at higher magnification in $D$. One of these cells appears to be migrating toward the $M Z$, whereas the other is directed toward the IZ. $E, F$, E16 slices maintained in culture for $3 \mathrm{~d}$ showed labeled cells predominantly in the $M Z, S P$, and lower aspect of the $I Z$. One of the migrating cells in the $\mathrm{MZ}$ is shown at higher magnification. $I C$, Insular cortex. Scale bars: $A, 60 \mu \mathrm{m} ; B$, $20 \mu \mathrm{m} ; C, 100 \mu \mathrm{m} ; D, 50 \mu \mathrm{m} ; E, 100 \mu \mathrm{m}$; $F, 20 \mu \mathrm{m}$.

erally or laterally to the pial surface (De Carlos et al., 1996) and then along plexuses of tangentially arranged axons within the preplate (Valverde et al., 1995). It has been suggested that axons can provide a substratum for nonradial neuronal migration (Gray et al., 1990; Rakic, 1990). At somewhat later stages, i.e., E15-16, labeled cells are seen rounding the corticostriatal sulcus, and their paths fork, directing some cells to the MZ and others to the SP and lower aspect of the IZ. The lower IZ and SP are the targets of cells labeled with DiI at E17. After this stage, MGE cells do not appear to migrate into the neocortex. Our placement of DiI in the LGE at E16 showed that in agreement with Anderson et al. (1997), labeled cells also migrated to the neocortex, but they were dispersed as GABA-containing interneurons in the IZ and throughout the CP but not in the MZ. The molecular mechanisms that control the migration of cells from the anlage of the basal ganglia into the neocortex are largely unknown. Analysis of mouse embryos carrying loss-of-function mutations in both Dlx1 and Dlx2 genes has shown that the dorsal migration of cells derived in the LGE is dependent on normal function of these genes (Anderson et al., 1997). The expression of both Dlx1 and Dlx2 in the MGE (Bulfone et al., 1993; Grigoriou et al., 1998) suggests that the dorsal migration of MGE-derived cells may also be under the control of this subfamily of homeobox genes. This hypothesis is further supported by recent findings that show absence of Lhx6-expressing cells in the cortex of Dlx1/Dlx2 null mouse embryos (Parnavelas et al., 1997).

What are the signals that control the dorsal migration of MGE cells during embryogenesis? The lesion experiments in which a cut was placed through the cortex at the level of the corticostriatal sulcus resulted in accumulation of MGE cells ventral to the cut. It 

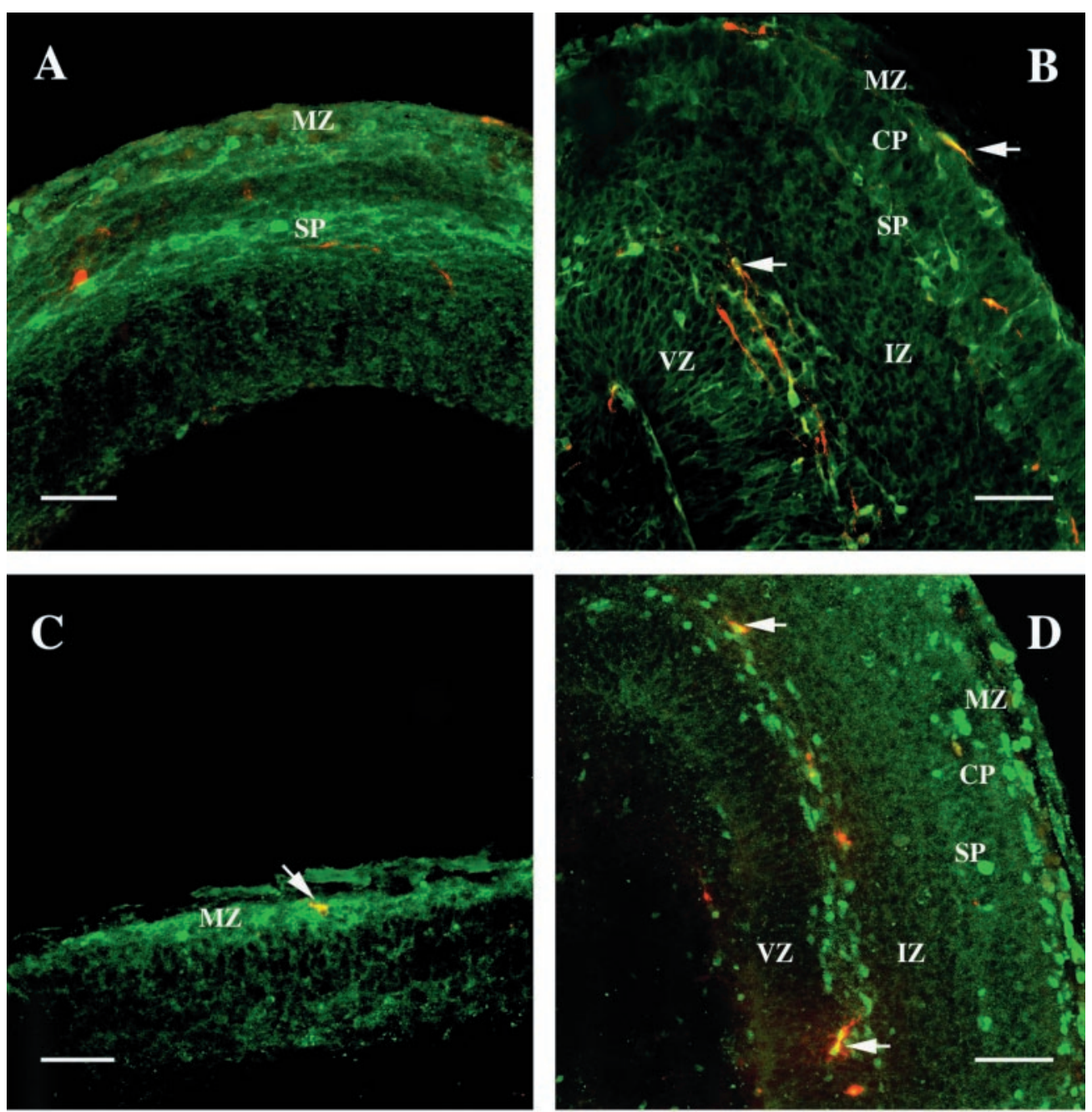

Figure 4. Immunohistochemistry was performed on DiI-labeled cortical cells that had originated in the MGE to assess the neurochemical phenotype. Such cells were found positive for GABA $(B$, yellow, arrows $)$, reelin $(C$, arrow $)$, and Lhx6 (D, yellow, arrows) but not for CR $(A)$. Single- and double-labeled cells in the lower $I Z$ in $B$ and $D$ are shown at higher magnification in $E$ and $F$, respectively. Scale bars, $100 \mu \mathrm{m}$.
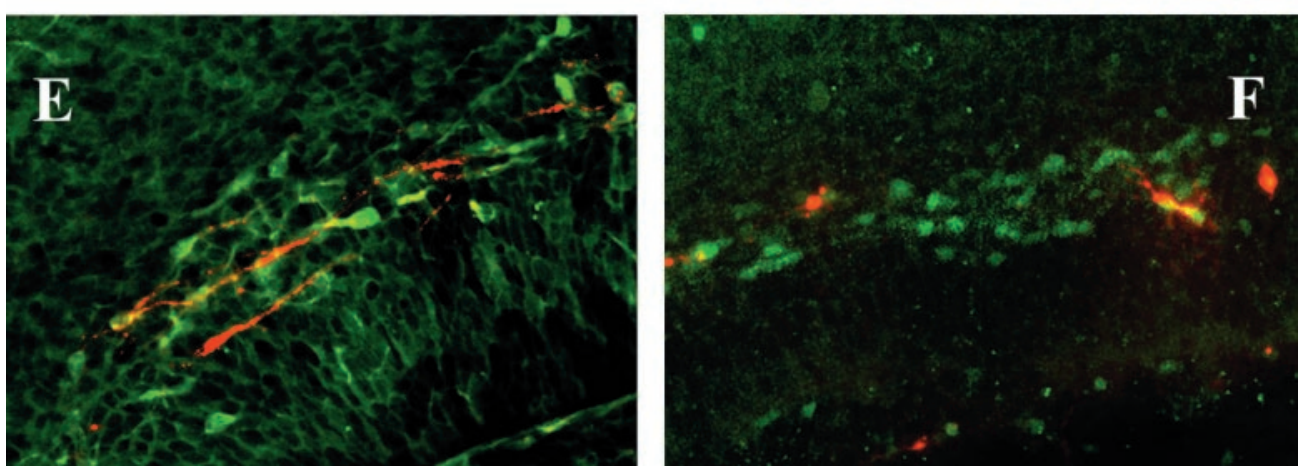

should be pointed out that direct comparisons between the lesioned and control sides are difficult to make because the exact placement and amount of DiI inserted in the MGE varies between the two sides. Also, we do not know whether all labeled cells seen ventral to the cut are actually destined for the neocortex. The accumulation of cells ventral to the cut would suggest that MGE cells do not depend on diffusible chemoattractive signals produced by the dorsally located neocortex to migrate to their destinations in its superficial and deep zones. Instead, they may follow a series of local cues that are present along their migratory pathway. These signals are presently unknown as is the mechanism that underlies the decision of migrating neurons to be directed toward the superficial or deep zones of the developing cortex.
Many of the neurons that migrate to the MZ differentiate into Cajal-Retzius cells that are identified by their morphological and neurochemical profiles. In agreement with earlier studies (Edmunds and Parnavelas, 1982; Marín-Padilla, 1984; Derer and Derer, 1990), they are readily recognized by their large size and tangentially oriented large processes. Furthermore, they stain for reelin, a secreted protein crucial for the establishment of normal lamination in the $\mathrm{CP}$, which has been detected in Cajal-Retzius cells of the developing cerebral cortex and hippocampus (Ogawa et al., 1995; Del Rio et al., 1997; Frotscher, 1997; Alcántara et al., 1998). However, they did not express CR, a calcium binding protein often used as a marker of Cajal-Retzius cells (Del Rio et al., 1995). These observations lend support to the notion that cells in the MZ comprise a heterogeneous group of neurons. This was 
initially postulated for primates, including humans (Meyer and Goffinet, 1998; Supèr et al., 1998), but work in other species has also shown that cells in the MZ show diverse morphologies and complex and different neurochemical profiles and fates (Bradford et al., 1977; Parnavelas and Edmunds, 1983; Derer and Derer, 1990; Meyer et al., 1998). One of the groups of neurons populating the $\mathrm{MZ}$ that has received attention since the early part of the century are the so-called subpial granule neurons. These cells were initially described only in the human cortex (Ranke, 1910; Brun, 1965; Gadisseux et al., 1992), but recent work by Meyer et al. (1998) has indicated that such cells, originating in a restricted sector of the telencephalic vesicle, also exist in the rat cortex. These authors further suggested that the derivatives of the subpial granule cells migrate into the superficial part of the $\mathrm{MZ}$ and differentiate into Cajal-Retzius cells. It may be that these neurons correspond to the Cajal-Retzius cells described here that have their origin in the MGE. However, the origins, patterns of migration, and differentiation of the diverse group of cells that populate the MZ need to be explored further.

Our fluorescent tracing experiments showed that MGE neurons also migrate to the IZ. However, only neurons labeled in a relatively narrow window of time (E15-17) were found in this zone. Similar experiments that involved placement of DiI in the LGE also showed a significant number of cells crossing the corticostriatal boundary and entering the IZ of the developing cortex (De Carlos et al., 1996; Tamamaki et al., 1997). Birthdating studies have shown that cells of the IZ are produced at the same time (E12-14) (De Diego et al., 1994; Tamamaki et al., 1997) as cells of the primordial preplate, except that cells continue to be added to this zone even after the appearance of the $\mathrm{CP}$. The functional role of these IZ neurons is not yet known, but their tangential movement and distribution indicate that they do not respect cortical area boundaries. What are the destinations and fate of these tangentially migrating IZ neurons? Studies that used GABA immunocytochemistry or bromodeoxyuridine labeling have shown that they accumulate as interstitial cells in the subcortical white matter (Kostovic and Rakic, 1980) and in the corpus callosum (De Diego et al., 1994). At caudal levels, they appear to invade the hippocampus (De Diego et al., 1994). It appears that these early generated IZ neurons are eliminated after birth (Kostovic and Rakic, 1980; Ferrer et al., 1990), suggesting a role for these cells in cortical development (Tamamaki et al., 1997).

A feature common to MGE cells that migrate to the MZ and IZ is the expression of the LIM homeobox gene Lhx6. This gene is a member of a novel subfamily of mammalian Lhx genes, designated $L h x 6$ and $L h x 7$ (Grigoriou et al., 1998). Overlapping domains of expression of $\operatorname{Lhx} 6$ and $L h x 7$ have been detected in the MGE of mouse and rat embryos [Grigoriou et al. (1998) and present results]. Lhx6 is expressed predominantly in the subventricular and submantle zones, and $L h x 7$ is expressed mainly in the submantle and mantle zones of the pallidal primordium. However, in the cortex, $\operatorname{Lh} x 6$ but not $\operatorname{Lh} x 7$ has been detected in the MZ, CP, IZ, and SP. This observation, together with the results of the DiI labeling experiments, suggests that the expression of Lhx6 in the cortex defines a subpopulation of cells that originate in the MGE and migrate dorsally crossing the corticostriatal boundary. It should be mentioned that the expression patterns of other homeobox and putative regulatory genes in the developing forebrain also show that the morphological corticostriatal boundary does not generally mark a limit of gene expression (Puelles and Rubenstein, 1993; Hallonet et al., 1998). Although the func- tion of $\operatorname{Lh} x 6$ and $\operatorname{Lh} x 7$ during mammalian embryogenesis is currently unknown, the pattern of expression of these genes in the developing MGE, along with the previously established role of other LIM/homeodomain proteins in cell fate decision and differentiation, suggests that $\operatorname{Lh} x 6$ and $\operatorname{Lh} x 7$ have a role in the generation and differentiation of the neuronal diversity in the basal forebrain. Furthermore, differential expression of these genes in a migratory population of MGE cells suggests that products of these genes uniquely or in combination with other transcription factors might play a role in the decision of MGE cells to differentiate in situ or migrate dorsally to the cortex.

The present findings taken together with tracing studies that focused on the LGE (De Carlos et al., 1996; Anderson et al., 1997; Tamamaki et al., 1997) clearly show that the ganglionic eminences contribute different cell types to the neuronal diversity of the mammalian cerebral cortex. These results strongly support the hypothesis of the evolution of the mammalian neocortex proposed first by Källén in the 1950s [see Karten (1997) for references] that was based on comparative embryological findings, and later by Karten and colleagues on histochemical evidence (Nauta and Karten, 1970; Karten, 1991, 1997). These authors postulated that the neurons that compose the large external striatum in reptiles and birds come to occupy the pallial mantle in mammals and form a major proportion of the cell population of the neocortex. The external striatum is known to arise in embryonic development by cell proliferation in the socalled dorsal ventricular ridge. In nonmammalian forms, its neuroblasts mature in situ without radical migration away from their matrix. However, neuroblasts generated in this region in the mammalian embryo migrate around the lateral corner of the telencephalic ventricle and invade the pallial mantle. Their proposed notion does not imply that the whole mammalian neocortex is homologous with the nonmammalian external striatum, but rather that neocortical neuronal populations homologous to those of the external striatum exist in the mammalian neocortex intermixed with the phylogenetically more recent populations of neurons originating in the pallium proper.

\section{REFERENCES}

Alcántara S, Ruiz M, D’Arcangelo G, Ezan F, de Lecea L, Curran T, Sotelo C, Soriano E (1998) Regional and cellular patterns of reelin mRNA expression in the forebrain of the developing and adult mouse. J Neurosci 18:7779-7799.

Anderson SA, Eisenstat DD, Shi L, Rubenstein JLR (1997) Interneuron migration from basal forebrain to neocortex: dependence on Dlx genes. Science 278:474-476.

Bradford R, Parnavelas JG, Lieberman AR (1977) Neurons in layer I of the developing occipital cortex of the rat. J Comp Neurol 176:121-132.

Brun A (1965) The subpial granular layer of the foetal cerebral cortex in man. Its ontogeny and significance in congenital cortical malformations. Acta Pathol Microbiol Scand [Suppl] 179:1-98.

Bulfone A, Puelles L, Porteus MH, Frohman MA, Martin GR, Rubenstein JL (1993) Spatially restricted expression of Dlx-1, Dlx-2 (Tes-1), Gbx-2, and Wnt-3 in the embryonic day 12.5 mouse forebrain defines potential transverse and longitudinal segmental boundaries. J Neurosci 13:3155-3172.

D'Arcangelo G, Miao GG, Chen SC, Soares HD, Morgan JI, Curran T (1995) A protein related to extracellular matrix proteins deleted in the mouse mutant reeler. Nature 374:719-723.

De Carlos JA, Lopez-Mascaraque L, Valverde F (1996) Dynamics of cell migration from the lateral ganglionic eminence in the rat. J Neurosci 16:6146-6156.

De Diego I, Smith Fernández A, Fairén A (1994) Cortical cells that migrate beyond area boundaries: characterization of an early neuronal population in the lower intermediate zone of prenatal rats. Eur J Neurosci 6:983-997.

Del Río JA, Martínez A, Fonseca M, Auladell C, Soriano E (1995) 
Glutamate-like immunoreactivity and fate of Cajal-Retzius cells in the murine cortex as identified with calretinin antibody. Cereb Cortex 5:13-21.

Del Río JA, Heimrich B, Borrell V, Förster E, Drakew A, Alcántara S, Nakajima K, Miyata T, Ogawa M, Mikoshiba K, Derer P, Frotscher M, Soriano E (1997) A role for Cajal-Retzius cells and reelin in the development of hippocampal connections. Nature 385:70-74.

Derer P, Derer M (1990) Cajal-Retzius cell ontogenesis and death in mouse brain visualized with horseradish peroxidase and electron microscopy. Neuroscience 36:839-856.

Edmunds SM, Parnavelas JG (1982) Retzius-Cajal cells: an ultrastructural study in the developing visual cortex of the rat. J Neurocytol 11:427-446.

Ferrer I, Bernet E, Soriano E, Del Rio T, Fonseca M (1990) Naturally occurring cell death in the cerebral cortex of the rat and removal of dead cells by transitory phagocytes. Neuroscience 39:451-458.

Fishell G (1995) Striatal precursors adopt cortical identities in response to local cues. Development 121:803-812.

Fishell G, Mason CA, Hatten ME (1993) Dispersion of neural progenitors within the germinal zones of the forebrain. Nature 362:636-638.

Frotscher M (1997) Dual role of Cajal-Retzius cells and reelin in cortical development. Cell Tissue Res 290:315-322.

Gadisseux JF, Goffinet AM, Lyon G, Evrard P (1992) The human transient subpial granular layer: an optical, immunohistochemical, and ultrastructural analysis. J Comp Neurol 324:94-114.

Ghosh A (1995) Subplate neurons and the patterning of thalamocortical connections. In: Development of the cerebral cortex (Ciba Foundation Symposium 193), pp 150-165. Chichester: Wiley.

Gray GE, Leber SM, Sanes JR (1990) Migratory patterns of clonally related cells in the developing central nervous system. Experientia 46:929-940.

Grigoriou M, Tucker AS, Sharpe PT, Pachnis V (1998) Expression and regulation of Lhx6 and Lhx7, a novel subfamily of LIM homeodomain encoding genes, suggests a role in mammalian head development. Development 125:2063-2074.

Hallonet M, Hollemann T, Wehr R, Jenkins NA, Copeland NG, Pieler T, Gruss P (1998) Vax1 is a novel homeobox-containing gene expressed in the developing anterior ventral forebrain. Development 125:2599-2610.

Karten HJ (1991) Homology and evolutionary origins of the "neocortex". Brain Behav Evol 38:264-272.

Karten HJ (1997) Evolutionary developmental biology meets the brain: the origins of mammalian cortex. Proc Natl Acad Sci USA 94:2800-2804.

Kemp JM, Powell TP (1971) The structure of the caudate nucleus of the cat: light and electron microscopy. Philos Trans R Soc Lond B Biol Sci 262:383-401.

Kostovic I, Rakic P (1980) Cytology and time of origin of interstitial neurons in the white matter in infant and adult human and monkey telencephalon. J Neurocytol 9:219-242.

Marín-Padilla M (1984) Neurons of layer I. A developmental analysis. In: Cerebral cortex, Vol 1, Cellular components of the cerebral cortex (Peters A, Jones EG, eds), pp 447-478. New York: Plenum.

Marín-Padilla M (1998) Cajal-Retzius cells and the development of the neocortex. Trends Neurosci 21:64-71.

McConnell SK, Ghosh A, Shatz CJ (1994) Subplate pioneers and the formation of descending connections from cerebral cortex. J Neurosci 14:1892-1907.

Meyer G, Goffinet AM (1998) Prenatal development of reelinimmunoreactive neurons in the human neocortex. J Comp Neurol 397:29-40

Meyer G, Soria JM, Martinez-Galan JR, Martin-Clemente B, Fairén A (1998) Different origins and developmental histories of transient neurons in the marginal zone of the fetal and neonatal rat cortex. J Comp Neurol 397:493-518.

Mione MC, Cavanagh JFR, Harris B, Parnavelas JG (1997) Cell fate specification and symmetrical/asymmetrical divisions in the developing cerebral cortex. J Neurosci 17:2018-2029.

Nauta WJH, Karten HJ (1970) A general profile of the vertebrate brain, with sidelights on the ancestry of cerebral cortex. In: The neurosciences, second study program (Schmitt FO, ed), pp 7-26. New York: The Rockefeller UP.
Neyt C, Welch M, Langston A, Kohtz J, Fishell G (1997) A short-range signal restricts cell movement between telencephalic proliferative zones. J Neurosci 17:9194-9203.

Ogawa M, Miyata T, Nakajima K, Yagyu K, Seike M, Ikenaka K, Yamamoto H, Mikoshiba K (1995) The reeler gene-associated antigen on Cajal-Retzius neurons is a crucial molecule for laminar organization of cortical neurons. Neuron 14:899-912.

O'Rourke NA, Sullivan DP, Kaznowski CE, Jacobs AA, McConnell SK (1995) Tangential migration of neurons in the developing cerebral cortex. Development 121:2165-2176.

Parnavelas JG, Edmunds SM (1983) Further evidence that RetziusCajal cells transform to nonpyramidal neurons in the developing rat visual cortex. J Neurocytol 265:863-871.

Parnavelas JG, Anderson SA, Lavdas AA, Grigoriou M, Pachnis V, Rubenstein JLR (1999) The contribution of the ganglionic eminence to the neuronal cell types of the cortex. In: Evolutionary developmental biology of the cerebral cortex (Novartis Foundation Symposium 228). Chichester: Wiley, in press.

Puelles L, Rubenstein JL (1993) Expression patterns of homeobox and other putative regulatory genes in the embryonic mouse forebrain suggest a neuromeric organization. Trends Neurosci 16:472-479.

Rakic P (1974) Neurons in rhesus monkey visual cortex: systematic relation between time of origin and eventual disposition. Science 183:425-427.

Rakic P (1988) Specification of cerebral cortical areas. Science 241:170-176.

Rakic P (1990) Principles of neural cell migration. Experientia 46:882-891.

Ranke G (1910) Beiträge zur kenntnis der normalen und pathologischen hirnrindenbildung. Zieglers Beiträge 47:51-125.

Rubenstein JL, Martinez S, Shimamura K, Puelles L (1994) The embryonic vertebrate forebrain: the prosomeric model. Science 266:578-580.

Schaeren-Wiemers N, Gerfin-Moser A (1993) A single protocol to detect transcripts of various types and expression levels in neural tissue and cultured cells: in situ hybridization using digoxigenin-labelled cRNA probes. Histochemistry 100:431-440.

Soriano E, Dumesnil N, Auladell C, Cohen Tannoudji M, Sotelo C (1995) Molecular heterogeneity of progenitors and radial migration in the developing cerebral cortex revealed by transgene expression. Proc Natl Acad Sci USA 92:11676-11680.

Supèr H, Soriano E, Uylings HBM (1998) The functions of the preplate in development and evolution of the neocortex and hippocampus. Brain Res Rev 27:40-64.

Szentágothai J (1973) Synaptology of the visual cortex. In: Handbook of sensory physiology, Vol VII/3, central processing of visual information, Part B (Jung R, ed), pp 269-324. Berlin: Springer.

Tamamaki N, Fujimori KE, Takauji R (1997) Origin and route of tangentially migrating neurons in the developing neocortical intermediate zone. J Neurosci 17:8313-8323.

Tan S-S, Faulkner Jones B, Breen SJ, Walsh M, Bertram JF, Reese BE (1995) Cell dispersion patterns in different cortical regions studied with an X-inactivated transgenic marker. Development 121:1029-1039.

Tan S-S, Kalloniatis M, Sturm K, Tam PPL, Reese BE, Faulkner-Jones B (1998) Separate progenitors for radial and tangential cell dispersion during development of the cerebral cortex. Neuron 21:295-304.

Uylings HBM, van Eden CG, Parnavelas JG, Kalsbeek A (1990) The prenatal and postnatal development of the rat cerebral cortex. In: The cerebral cortex of the rat (Kolb E, Tees RC, eds), pp 35-76. Cambridge, MA: MIT.

Vaccarino FM, Schwartz ML, Hartigan D, Leckman JF (1995) Basic fibroblast growth factor increases the number of excitatory neurons containing glutamate in the cerebral cortex. Cereb Cortex 5:64-78.

Valverde F, De Carlos JA, Lopez-Mascaraque L (1995) Time of origin and early fate of preplate cells in the cerebral cortex of the rat. Cereb Cortex 5:483-493.

Van Eden CG, Mrzljak L, Voorn P, Uylings HB (1989) Prenatal development of GABA-ergic neurons in the neocortex of the rat. J Comp Neurol 289:213-227.

Walsh C, Cepko CL (1992) Widespread dispersion of neuronal clones across functional regions of the cerebral cortex. Science 255:434-440. 